\title{
Maternal Inheritance of Yellowfin Tuna (Thunnus albacares) in Captivity
}

\author{
Gusti Ngurah Permana ${ }^{1}$, Jhon Harianto Hutapea ${ }^{1}$, Sari Budi Moria ${ }^{1}$ and Ketut Sugama ${ }^{2}$ \\ 1. Biotechnology Laboratory, IMRAD (Institute for Mariculture Research and Development) at Gondol, Singaraja Bali 140, \\ Indonesia \\ 2. Research Center for Aquaculture, Jakarta 12540, Indonesia
}

\begin{abstract}
Mitochondrial DNA introgression has been suggested to be responsible for the maternal consistent implications. Study on mt-DNA (mitochondrial DNA) variation in the yellowfin tuna (Thunnus albacares) using RFLP (restriction fragment length polymorphisms) has provided the evidence of maternal inheritance of yellowfin tuna in captivity. Eggs were collected in every spawning in 2004-2006 season. The mt-DNA genotypes of broodstock were compared with their eggs and the maternal inheritance of these females was determined from genotypes in the eggs. The result showed that six genotypes of female broodstock were observed in eggs and four of them were found to share a single female's identity and one type was shared by two females. The same genotype was observed in almost every sampling throughout the year. The female broodstocks spawned almost daily throughout the season.
\end{abstract}

Key words: Genotype, mt-DNA, maternal inheritance, yellowfin tuna.

\section{Introduction}

Yellowfin tuna (T. albacares (Thunnus albacares)) is a cosmopolitan fish species inhabiting tropical and subtropical waters in the Atlantic, Pacific, and Indian Oceans. Yellowfin tuna is a large pelagic fish with a common size of $150 \mathrm{~cm}$ [1]. Spawning occurs throughout the year in the tropical oceans, preferably near islands and coasts [2]. The Indian Ocean of Java and Bali Islands are important spawning ground of tuna species, so this area contributes greatly to the conservation of the species.

IMRAD (Institute for Mariculture Research and Development) at Gondol, Bali initiated yellowfin tuna propagation in land-based facilities under research cooperation with OFCF (Overseas Fisheries Cooperation Foundation) in Japan. Previously the similar project was started among OFCF, AITTC (Inter America Tropical Tuna Commision) in Panama

Corresponding author: Gusti Ngurah Permana, master, research field: biotechnology in aquaculture. E-mail: gustipermana@gmail.com.
$[3,4]$. The project site in Bali was established to collect scientific data of tuna species, especially yellowfin tuna (T. albacares).

The first spawning occurred in August 2004, and continued spawning through 2005. Strict maternal inheritance of mt-DNA (mitochondrial DNA) in vertebrates may be feasible for identifying reproductively active females. In sexually reproducing organisms, mitochondria are normally inherited exclusively from the mother. The mitochondria in fish sperm are usually destroyed by the egg cell after fertilization. In addition, most mitochondria are present at the base of the sperm's tail, which is used for propelling the sperm cells. Sometimes the tail is lost during fertilization. Usage marker mt-DNA (mitochondria DNA) is easy to understand and apply to know pattern of genetic endowment that is indigenous to female individual (maternal inheritance) $[5,6]$. All the mitochondria come from the mother, therefore, any defect is passed on through the generations from parent to offsprings. This research aimed to identify maternal pattern from mt-DNA 
genotypes comparing between broodstock and their offsprings to identify females contributing to spawn. The study will have important implication not only for our understanding of mitochondrial genetics but also for increasing spawning productivity of yellowfin tuna as well.

\section{Materials and Methods}

\subsection{Broodstock}

The main broodstock tank was designed to be large enough to reduce the stress of captivity and to enhance the chances of spawning. Twenty five yellowfin tunas were maintained in the main broodstock tank $(18 \mathrm{~m}$ in diameter, $6 \mathrm{~m}$ in depth with working volume of 1.526 $\mathrm{m}^{3}$ ). Vertical black stripes, $2.5 \mathrm{~cm}$ wide at $65 \mathrm{~cm}$ intervals, were painted on the entire interior tank wall to improve visibility of the wall. Spawning of captive yellowfin tuna occurred in 2004 in a land-based tank at IMRAD [7, 8].

Each fish was tagged with a microchip implant tag in the dorsal musculature for individual identification at stocking. A small piece of finlet from all group individuals was clipped at stocking. These tissue samples were preserved in ethanol 95\%. The yellowfin tuna broodstock was fed with 50\% fish (mostly scad mackerel of fork-length was $10-15 \mathrm{~cm}$ ) and $50 \%$ squid of about $12-18 \mathrm{~cm}$ once a day at an average daily ration of $2 \%-3 \%$. A premixed vitamin powder supplement was added at $0.5 \%-1.0 \%$ of the food weight.

\subsection{Eggs}

Spawning occurred almost daily in the broodstock tank from October 2004 to May 2006. Fertilized eggs were collected for DNA analysis from 98 spawning events at daily to two-week interval from October-November 2004, and next spawning season from August 2005 to May 2006. The eggs were collected with a net $\left(0.8 \mathrm{~m}^{2}\right)$ and number of eggs was counted after every spawning. Collected fertilized eggs were between 50,000-100,000.

\subsection{DNA Analysis}

Samples were preserved in $500 \mu \mathrm{L}$ of ethanol $95 \%$ and analyzed in National Far Sea Fisheries Laboratory Shimidzu-Japan and Biotechnology Laboratory at IMRAD Gondol-Bali Indonesia. The egg samples and finlet were extracted using phenol chloroform [9]. The DNA from the larvae, eggs and yellowfin broodstock was rehydrated with 10-30 $\mu \mathrm{L}$ TE (Tris EDTA) buffer. The two primers CB3R-LT and 12SAR-H were used to amplify the Dloop region of mt-DNA following Palumbi et al. [10]; their sequences are 5'CACATTAAACCTGAATGATATTT-'3 and 3' ATAGTGGGGTATCTAATCCCAGTT-5', respectively. The PCR (polymerase chain reaction) was carried out in $25 \mu \mathrm{L}$ total volume with an initial denaturation at $95{ }^{\circ} \mathrm{C}$ for $3 \mathrm{~min}$ with followed by 30 cycles of amplification (denaturation at $95{ }^{\circ} \mathrm{C}$ for $1 \mathrm{~min}$, annealing at $50{ }^{\circ} \mathrm{C}$ for $1 \mathrm{~min}$ and extension at $72{ }^{\circ} \mathrm{C}$ for $2 \mathrm{~min}$ ) with a final extension at $72{ }^{\circ} \mathrm{C}$ for $10 \mathrm{~min}$. The PCR products were directly digested by each of five restriction enzymes endonucleases (DdeI, MnlI, MspI, NlaIII and TaqI). These enzymes were selected by preliminary screening of the RFLP (restriction fragment length polymorphisms) in this DNA fragment using yellowfin individuals [11]. Digested PCR samples were electrophoreses through $2.5 \%$ agarose gel (Biogel, BIO101), followed by ethidium bromide staining and that was photographed.

\section{Results and Discussion}

\subsection{Genotypes of Broodstock Individuals}

Stocking and biological profiles of 25 broodstock yellowfin tunas were shown in Table 1. The amplified fragment size of each mt-DNA segment was estimated to be about 1,900 bp (base pair), and no apparent size difference among individuals was observed. Of the total of 25 broodstocks and 222 eggs of yellowfin tuna examined, it was found that the numbers of observed genotypes in each restriction assay using MspI, DdeI and MnlI, TaqI and NlaIII were two, three, five and eight, respectively. 
Genotypes of yellowfin tuna were obtained by the five restriction analyses produced determining 20 composite genotypes, of which 10 established a single individual's identity, five were shared by two individuals (Table 2). This finding is in concordance to the result of a study in Panama Achotines Laboratory applying six restriction enzymes for mt-DNA-Dloop region [11], which showed that less than $30 \%$ of females contributed to spawning. Most of the fish in the tank appeared to participate in daily courtship and prespawning activities, which was usually a good indicator of participation in spawning in the tank. Therefore, it is likely that the number of spawning females was underestimated in this genetic analysis due to the conservative sampling frequency and sample sizes.

\subsection{Genotypes of Eggs}

Four composite genotypes were detected, and these composite genotypes matched those of five broodstock during 2004-2005 female yellowfin tuna (Table 3). One composite genotype (type B10) was shared by two yellowfin tuna broodstocks (Table 4).

Maternal inheritance has a great influence on the offspring's gene expression [12, 13]. Mitochondrial genes, in contrast to genes in the nucleus, have an exclusively maternal mode of inheritance in mammals [14]. This should be a weakness of this study. Nuclear

Table 1 Stocking (tag code) and biological profile of 25 broodstock of yellowfin tuna.

\begin{tabular}{|c|c|c|c|c|}
\hline No. of fish & Code No. & Date of transfer & Tag No. & $\begin{array}{l}\text { Fork length at capture } \\
(\mathrm{cm})\end{array}$ \\
\hline 1 & $\mathrm{~B} 1$ & September 1, 2003 & 4213747E0E & 51.0 \\
\hline 2 & B2 & September 30, 2003 & 42137B0450 & 32.0 \\
\hline 3 & B3 & October 17, 2003 & 42137F5578 & 47.0 \\
\hline 4 & B4 & October 24, 2003 & 42137A0567 & 52.0 \\
\hline 5 & B5 & October 30, 2003 & 4213601A0E & 48.3 \\
\hline 6 & B6 & October 30, 2003 & 42137A026A & 55.0 \\
\hline 7 & B7 & November 6, 2003 & 42137F0B17 & 51.0 \\
\hline 8 & B8 & November 7, 2003 & 42135B0A2F & 47.0 \\
\hline 9 & B9 & November 7, 2003 & 42135A1D48 & 47.0 \\
\hline 10 & $\mathrm{~B} 10$ & November 14, 2003 & 4213683511 & 37.0 \\
\hline 11 & B11 & December 5, 2003 & $421363684 \mathrm{D}$ & 51.0 \\
\hline 12 & $\mathrm{~B} 12$ & March 19, 2004 & 42136E4F0C & 72.0 \\
\hline 13 & $\mathrm{~B} 13$ & March 19, 2004 & 421370090B & 72.5 \\
\hline 14 & B14 & March 19, 2004 & 4213766F34 & 71.0 \\
\hline 15 & B15 & March 19, 2004 & $421378445 \mathrm{~A}$ & 67.0 \\
\hline 16 & B16 & March 19, 2004 & 4214012A5E & 68.0 \\
\hline 17 & B17 & June 7, 2004 & 4213591A36 & 60.0 \\
\hline 18 & B18 & June 16, 2004 & 42135D6741 & 65.0 \\
\hline 19 & B19 & August 5, 2004 & 42137F611F & 64.0 \\
\hline 20 & $\mathrm{~B} 20$ & June 28, 2004 & 42137C5D4D & 61.0 \\
\hline 21 & B21 & April 23, 2004 & 4213637241 & 64.5 \\
\hline 22 & $\mathrm{~B} 22$ & May 6, 2005 & $4210312 \mathrm{D} 74$ & 70.0 \\
\hline 23 & $\mathrm{~B} 23$ & May 6, 2005 & $42135 \mathrm{E} 332 \mathrm{~F}$ & 82.0 \\
\hline 24 & B24 & May 6, 2005 & $42102 \mathrm{~F} 205 \mathrm{~B}$ & 69.0 \\
\hline 25 & $\mathrm{~B} 25$ & May 6, 2005 & 420B4A4F3B & 74.0 \\
\hline
\end{tabular}


Table 2 Maternal evidence from restriction profile of yellowfin tuna broodstocks and eggs observed in Dloop region mt-DNA.

\begin{tabular}{|c|c|c|c|c|c|c|c|c|}
\hline \multirow{2}{*}{$\begin{array}{l}\text { Genotype } \\
\text { No. } \\
\text { B1 }\end{array}$} & \multicolumn{5}{|c|}{ Haplotype in broodstock } & \multirow{2}{*}{$\begin{array}{l}\text { Number of individuals } \\
1\end{array}$} & \multirow[t]{2}{*}{ Genotype detected in egg } & \multirow[t]{2}{*}{ Sex identified } \\
\hline & $\mathrm{B}$ & $\mathrm{B}$ & $\mathrm{B}$ & $\mathrm{B}$ & A & & & \\
\hline B2 & B & $\mathrm{B}$ & B & $\mathrm{D}$ & A & 1 & & \\
\hline B3 & $\mathrm{E}$ & $\mathrm{B}$ & A & $\mathrm{B}$ & $\mathrm{C}$ & 1 & EBABC & Female \\
\hline B4 & $\mathrm{E}$ & A & A & $\mathrm{E}$ & $\mathrm{B}$ & 2 & & \\
\hline B5 & $\mathrm{C}$ & $\mathrm{B}$ & B & A & B & 1 & & \\
\hline B6 & $\mathrm{C}$ & A & B & $\mathrm{E}$ & A & 1 & & \\
\hline B7 & A & $\mathrm{B}$ & A & B. & A & 1 & ABABA & Female \\
\hline B8 & $\mathrm{C}$ & A & A & $\mathrm{D}$ & B & 2 & & \\
\hline B9 & $\mathrm{D}$ & $\mathrm{B}$ & B & $\mathrm{C}$ & A & 1 & DBBCA & Female \\
\hline B10 & $\mathrm{D}$ & $\mathrm{A}$ & B & $\mathrm{E}$ & A & 2 & DABEA & Female \\
\hline B11 & $\mathrm{C}$ & B & B & $\mathrm{D}$ & B & 1 & & \\
\hline B12 & $\mathrm{C}$ & A & B & $\mathrm{D}$ & B & 2 & & \\
\hline B13 & B & A & B & A & A & 1 & BABAA & Female \\
\hline B14 & B & A & B & $\mathrm{E}$ & A & 1 & & \\
\hline B15 & $\mathrm{C}$ & B & B & $\mathrm{C}$ & A & 2 & & \\
\hline
\end{tabular}

Table 3 Composite genotype of eggs of October-November 2004 to September-December 2005.

\begin{tabular}{|c|c|c|c|c|c|c|c|}
\hline \multirow{2}{*}{ Date of spawning } & \multirow{2}{*}{ Genotype No. } & \multicolumn{5}{|c|}{ Restriction enzymes } & \multirow{2}{*}{-Number of samples } \\
\hline & & Taq1 & Msp & MnlI & Nla III & DdeI & \\
\hline October 26-31, 2004 & B-13 & $\mathrm{B}$ & A & $\mathrm{B}$ & A & A & 20 \\
\hline November 1-3, 2004 & B-13 & $\mathrm{B}$ & A & $\mathrm{B}$ & $\mathrm{A}$ & A & 20 \\
\hline September 1-6, 2005 & B-7 & $\mathrm{E}$ & $\mathrm{B}$ & A & $\mathrm{B}$ & A & 10 \\
\hline \multirow{2}{*}{ September 7-8, 2005} & B-7 & $\mathrm{E}$ & $\mathrm{B}$ & A & $\mathrm{B}$ & A & 10 \\
\hline & B-3 & $\mathrm{E}$ & $\mathrm{B}$ & A & $\mathrm{B}$ & $\mathrm{C}$ & 1 \\
\hline \multirow{2}{*}{ September 12-21, 2005} & B-7 & $\mathrm{E}$ & $\mathrm{B}$ & A & $\mathrm{B}$ & A & 10 \\
\hline & B-3 & $\mathrm{E}$ & $\mathrm{B}$ & A & $\mathrm{B}$ & $\mathrm{C}$ & 5 \\
\hline September 24-30, 2005 & B-7 & $\mathrm{E}$ & $\mathrm{B}$ & A & $\mathrm{B}$ & $\mathrm{A}$ & 10 \\
\hline October $1-26,2005$ & B-7 & $\mathrm{E}$ & $\mathrm{B}$ & A & $\mathrm{B}$ & A & 10 \\
\hline \multirow{2}{*}{ October 27-30, 2005} & B-7 & $\mathrm{E}$ & $\mathrm{B}$ & A & $\mathrm{B}$ & A & 11 \\
\hline & B-3 & $\mathrm{E}$ & A & $\mathrm{B}$ & $\mathrm{E}$ & $\mathrm{C}$ & 5 \\
\hline November 1-3, 2005 & B-7 & $\mathrm{E}$ & $\mathrm{B}$ & A & $\mathrm{B}$ & A & 10 \\
\hline November 4, 2005 & B-3 & $\mathrm{E}$ & $\mathrm{B}$ & A & $\mathrm{B}$ & $\mathrm{C}$ & 5 \\
\hline November 7, 2005 & B-3 & $\mathrm{E}$ & $\mathrm{B}$ & A & $\mathrm{B}$ & $\mathrm{C}$ & 10 \\
\hline \multirow{3}{*}{ November 8-9, 2005} & B-7 & $\mathrm{E}$ & $\mathrm{B}$ & A & $\mathrm{B}$ & A & 10 \\
\hline & B-3 & $\mathrm{E}$ & $\mathrm{B}$ & A & $\mathrm{B}$ & $\mathrm{C}$ & 10 \\
\hline & B-3 & $\mathrm{E}$ & $\mathrm{B}$ & A & $\mathrm{B}$ & $\mathrm{C}$ & 5 \\
\hline November 10-13, 2005 & B-7 & $\mathrm{E}$ & $\mathrm{B}$ & A & $\mathrm{B}$ & A & 10 \\
\hline November 14, 2005 & B-7 & $\mathrm{E}$ & $\mathrm{B}$ & A & $\mathrm{B}$ & A & 10 \\
\hline November 15-20, 2005 & B-3 & $\mathrm{E}$ & $\mathrm{B}$ & $\mathrm{A}$ & $\mathrm{B}$ & $\mathrm{C}$ & 5 \\
\hline \multirow{2}{*}{ November 21-30, 2005} & B-7 & $\mathrm{E}$ & $\mathrm{B}$ & A & $\mathrm{B}$ & A & 5 \\
\hline & B-10 & $\mathrm{D}$ & $\mathrm{A}$ & $\mathrm{B}$ & $\mathrm{E}$ & A & 2 \\
\hline \multirow{2}{*}{ December 1-15, 2005} & B-7 & $\mathrm{E}$ & $\mathrm{B}$ & A & $\mathrm{B}$ & A & 10 \\
\hline & B-10 & $\mathrm{D}$ & A & $\mathrm{B}$ & $\mathrm{E}$ & A & 6 \\
\hline December 16-24, 2005 & B-3 & $\mathrm{E}$ & $\mathrm{B}$ & $\mathrm{A}$ & B & $\mathrm{C}$ & 12 \\
\hline
\end{tabular}


Table 4 Maternal pattern detected in eggs and homologous female yellowfin tuna broodstocks.

\begin{tabular}{llll}
\hline Haplotype No. & Number of fish & Female broodstock predicted & Genotype detected in egg \\
\hline B-3 & 1 & EBABC & EBABC \\
B-7 & 1 & ABABA & ABABA \\
B-9 & 1 & DBBCA & DBBCA \\
B-10 & 2 & DABEA & DABEA \\
B13 & 1 & BABAA & BABAA \\
\hline
\end{tabular}

DNA should give more information on the inheritance including Mendelian inheritance of yellowfin tuna, as evidenced in previous publications [6, 15]. Furthermore, the study of spawning should be confirmed using histological approach. Fresh postovulatory follicles in the gonads of fully mature females are convincing evidences of recently spawned fishes. Study on the histological analysis of the gonads of wild yellowfin tuna has indicated that females apparently can spawn on near-daily intervals [2]. The result of this study shows that captive yellowfin spawns daily support the finding that reproductively active yellowfin females spawn every 1.27-1.52 days on average [2]. To proof the mitochondrial maternal inheritance, the sequences of broodstocks and eggs should be compared.

In the future, the analyses of maternal inheritance would be conducted using sequencing method of mitochondrial DNA fragments. Targeting highly polymorphic gene fragments are more accurate, especially in the processing of large numbers of tuna samples [16].

\section{Conclusions}

Twenty haplotypes were detected from broodstock of yellowfin tuna during experiment and six of them were female. Female yellowfin tuna broodstock can spawn every day and several females contributed to spawning in a single day. Furthermore, research is needed to determine the clear mechanism involved in maternal inheritance. In addition, paternal inheritance in selective breeding would be more elucidated using nuclear DNA analysis on polymorphic gene loci.

\section{Acknowledgments}

The authors would like to thank Prof. Dr. Gusti Ngurah Kade Mahardika and Gede Suwarthama Sumiarsa, Ph.D., for reviewing this manuscrips. We also give thanks to Dr. Nobuaki Suzuki, scientists of the National Research Institute of Far Seas Fisheries Laboratory, Orido, Shimizu Japan for generously providing equipment and valuable information during the research. This research was supported by Center for Aquaculture Research and Development in Indonesia and Japan Overseas Fishery Cooperation Foundation.

\section{References}

[1] Collette, B. B., and Nauen, C. E. 1983. "Scombrids of the World. An Annotated and Illustrated Catalogue of Tunas, Mackerels, Bonitos and Related Species Known to Date." FAO Fisheries Synopsis 125 (2): 1-137.

[2] Schaefer, K. M. 1998. "Reproductive Biology of Yellowfin Tuna (Thunnus albacares) in the Eastern Pacific Ocean." Inter-Am. Trop. Tuna Comm. Bull 21: 201-72.

[3] Wexler, J. B., Margulies, D., Masuma, S., Tezuka, N., Teruya, K., Oka, M., Kanematsu, M., and Nikaido. H. 2001. "Age Validation and Growth of Yellowfin Tuna, Thunnus Albacares, Larvae Reared in the laboratory." Inter-Am. Trop. Tuna Comm., Bull 22: 52-91.

[4] Wexler, J. B., Scholey, V. P., Olson, R. J., Margulies, D., Nakazawa, A., and Suter, J. M. 2003. "Tank Culture of Yellowfin Tuna, Thunnus Albacares: Developing a Spawning Population for Research Purposes." Aquaculture 220: 327-53.

[5] Iguchi, K., Tanimura, Y., Takeshima, H., and Nishida, M. 1999. "Genetic Variation and Geographic Population Structure of Amphidromous Ayu Plecoglossus altivelis as Examined by Mitochondrial DNA Sequencing." Fisheries Science 65 (1): 63-7.

[6] Chow, S., and Takeyama, H. 2000. "Nuclear and Mitochondrial DNA Analyses Reveal Four Genetically 
Separated Breeding Units of the Swordfish (Xiphias gladius)." J. Fish Biol. 56: 1087-98.

[7] Hutapea, J. H., Permana, G. N., Nakazawa, A., and Kitagawa, T. 2003. "Preliminary Study of Yellowfin Tuna (Thunnus albacares) Capture for Candidate Broodstock." In Proceedings of International Marine and Fisheries Seminar, 31-3.

[8] Hutapea, J. H., Permana, G. N., and Andamari, R. 2007. "Optimum Captured Size of Yellowfin Tuna (Thunnus albacares) Broodstock." In Proceedings of Indonesian Aquaculture Conference, 312-7.

[9] Maniatis, T., Fritch, E. F., and Sambrook, K. J. 1982. Molecular Cloning. A Laboratory Manual. New York: Cold Spring Harbour Laboratory Press.

[10] Palumbi, S. R., Martin, A., Romano, S., McMillan, W. O., Stice, L., and Grabowski, G. 1991. The Simple Fool's Guide to PCR. Version 2. Honolulu: Zoology Department, University of Hawaii.

[11] Niwa, Y., Nakazawa, A., Margulies, D., Scholey, V. P., Wexler, J. B., and Chow, S. 2003. "Genetic Monitoring for Spawning Ecology of Captive Yellowfin Ttuna (Thunnus albacares) Using Mitochondrial DNA Variation." Aquaculture 218: 387-95.

[12] Chow, S., Scholey, V. P., Nakazawa, A., Marguiles, D.,
Wexler, J. B., Olson, H. R., and Hazama, K. 2001. "Direct Evidence for Mendelian Inheritance of the Ribosomal Protein Gen Intron Variations in the Yellowfin Tuna (Thunnus albacares)." Mar. Biotechnol. 3: 22-6.

[13] Masuma, S., Tezuka, N., Obana, H., Suzuki, N., Nohara, K., and Chow, S. 2003. "Spawning Ecology of Captibe Bluefin Tuna (Thunnus thynnus orientalis) Inferred by Mitochondrial DNA Analysis." Bull Fish. Res. Agen. 6 (128): 9-14.

[14] Giles, R. E., Blanc, H., Cann, H. M., and Wallace, D. C. 1980. "Maternal Inheritance of Human Mitochondrial DNA.” Proc Natl Acad Sci USA 77: 6715-9.

[15] Takagi, M., Chow, S., Okamura, T., Scholey, V. P., Nakazawa, A., Margulies, D., Wexler, J. B., and Taniguchi, N. 2003. "Mendelian Inheritance and Variation of Four Microsatellite DNA Markers in the Yellowfin Tuna Thunnus albacares." Fisheries Science 69: 1306-8.

[16] Orita, M., Iwahana, H., Kanazawa, H., Hayashi, K., and Sekiya, T. 1989. "Detection of Polymorphisms of Human DNA by Gel Electrophoresis as Single-Strand Conformation Polymorphisms." Proc. Natl. Acad. Sci. 86: 27, 66-70. 